\title{
Assessment of the Environmental Conditions of Abattoirs in Minna, Nigeria
}

\author{
${ }^{1}$ Olujimi Julius, ${ }^{2 *}$ Akinbode Temitope, and ${ }^{3}$ Badawi Ibraihim \\ ${ }^{1-2}$ Department of Urban and Regional Planning, Federal University of Technology, Akure, Nigeria. \\ ${ }^{3}$ Department of Urban and Regional Planning, Federal University of Technology, Minna, Nigeria.
}

"Corresponding Author E-mail: takinbode@futa.edu.ng; $\quad$ Tel: 08034334573

Submitted on: $180 / 01 / 2021$

Accepted on: $23 / 04 / 2021$

\begin{abstract}
Environmental conditions of abattoirs in Minna, Nigeria was examined by assessing the level of facilities available, the extent of environmental damages, and the implications of operational activities of the abattoirs on the neighbouring communities. Multi-stage sampling technique was used for the questionnaire administration. Field data were collected by administering two different sets of structured questionnaires to abattoir operators and residents around the sampled abattoirs. In-situ observations and photographs of interesting scenarios were taken to support part of the findings. Analysis was done using descriptive statistics. The findings revealed that most of the abattoirs were inadequately equipped, un-hygienically managed and weakly regulated, which resulted to negative environmental impacts on the neighbouring land uses. Proper management, improvement on the design of the abattoir and ensuring good regulatory policies among others were suggested to reduce the negative impacts of the abattoirs.
\end{abstract}

Keywords: Abattoir, operating standard, environmental pollution, waste management

\section{Introduction}

In recent decades, the world has witnessed several environmental (natural and anthropogenic) disasters on different fronts. The natural environmental disasters are attributed to factors relating to natural occurrence. However, human factors sometimes triggered the occurrence of natural disaster such as building on water ways. Man-made environmental disaster is attributed to the activities of man on earth in violation of applicable laws and order. Recently, developing countries have witnessed serious environmental disaster due to abuse, inadequate or lack of proper environmental planning and monitoring.

A major source of environmental pollution is the abattoir. According to the World Health Organization, WHO (2005), because of the high level of alteration of the balance of gases in the atmosphere, abattoirs have been identified as a major source of air pollution worldwide. Increased pollution in abattoirs arises as a result of the continuous effort to increase meat production in order to meet the protein demand of the ever-increasing world population. The act comes with some pollution problems being experienced globally. Chukwu and Adeoye (2011), and Akinro et al. (2009) pointed out that, some of the environmental pollutions which arose from the activities in meat production are as a result of failure in adhering to Good Manufacturing Practices (GMP) and Good Hygiene Practices (GHP).

In Nigeria, particularly Minna, livestock industries and slaughter houses are cluttered with non-meat products and wastes that need to be disposed or recycled into other useful products for other industrial uses. This unruffled approach constitutes public health hazards and nuisance in most slaughter houses spread across Nigerian markets. Clean and safe environment is considered as a 
basic requirement for human health and wellbeing. However, poor physical development, which includes human activities (abattoirs) that are generally known all over the world to pollute the environment either directly or indirectly from their various processes and on various fronts (water pollution, air pollution, land pollution, odor, etc) continue to degrade the environment. Abattoir waste, just like any other waste, can be harmful to humans and the environment. The nonchalant attitude of the operators has the ability to damage our environment if good certain steps are not taken.

This study assessed the environmental conditions of abattoirs in Minna, Niger State capital in Nigeria. The study investigated into the level of adequacy and functionality of the facilities, environmental conditions of the abattoirs and its likely implications on man and animals. This is with a view to identifying the gray areas in order to suggest possible solutions to the identified environmental-related challenges.

\section{The Study Area}

Minna is about $100 \mathrm{~km}$ from Abuja, the Federal Capital Territory of Nigeria (Figures 1 and 2). It is located between latitude $9^{0} 36^{\prime} 50^{1} \mathrm{~N}$ and longitude $6^{0}, 33^{\prime} 25^{11} \mathrm{E}$ with a population of approximately 506,113 . Added to this, is the population of its environs thereby resulted into a high demand for meat consumption, hence the need for abattoir. The average population density in Minna is about 3,448 persons per $\mathrm{km}^{2}$ (UNDP/NISEPA, 2009). The climatic condition of the study area supports rearing of animals and operation of abattoir as noted by Food and Agricultural Organisation of the United Nations (2013). Climatic condition is one of the factors that influences the location and operations of abattoirs. The study area is located in a tropical climatic region which is characterized by two seasons in a year (the wet and dry seasons).

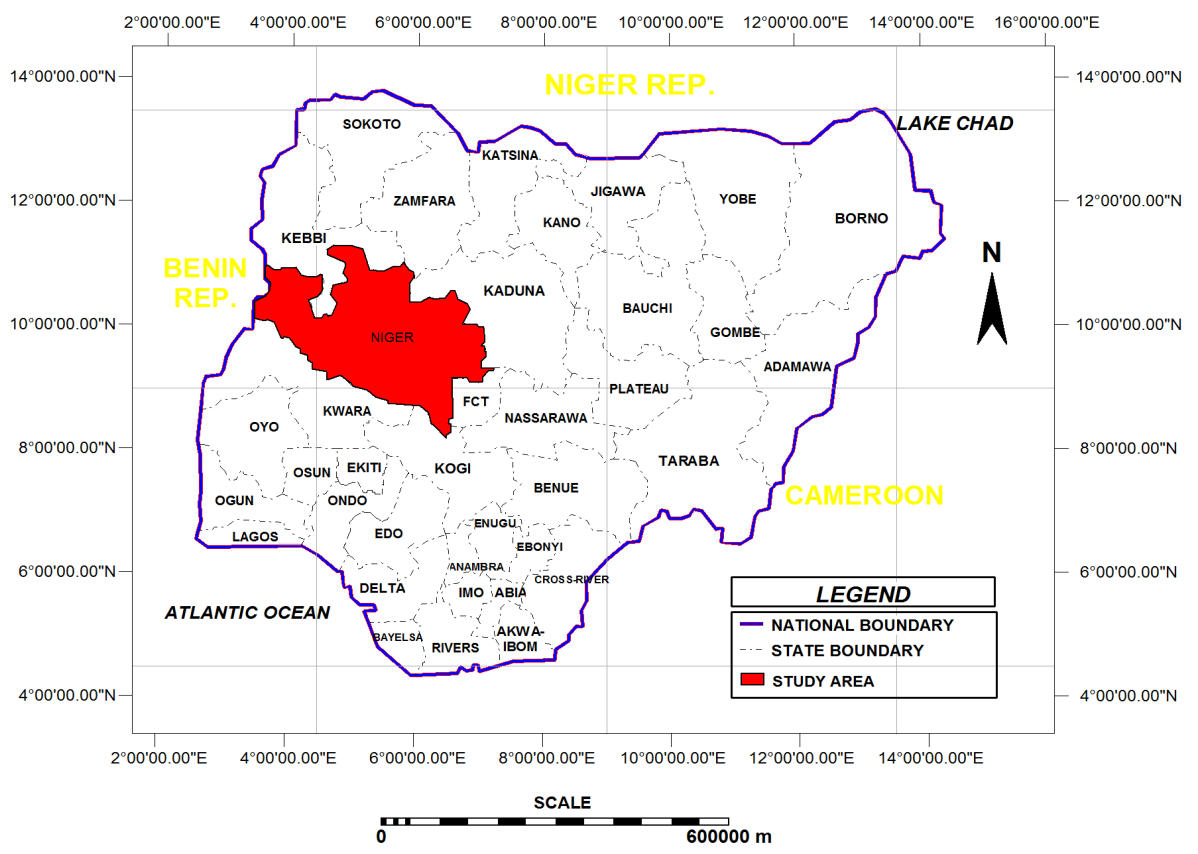

Figure 1. Niger State in national context.

Source: Ministry of Land and Survey, Minna, Niger State, 2017. 
LAUTECH Journal of Civil and Environmental Studies Volume 6, Issue 2

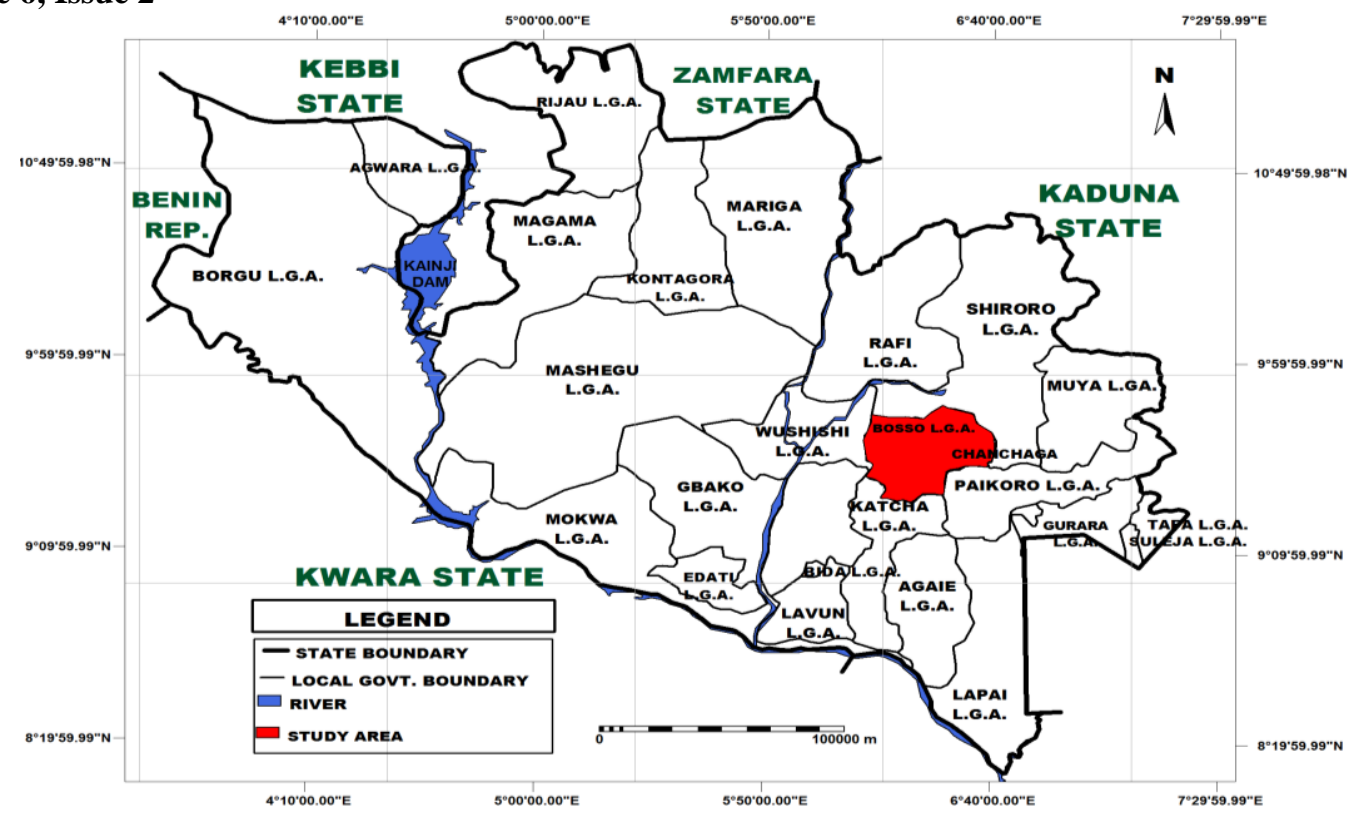

Figure 2. The study area (Minna) in the context of Niger State.

Source: Ministry of Land and Survey, Minna, Niger State, 2017.

The annual rainfall received within the region is less than $1,000 \mathrm{~mm}$ in the wet season and lasts between May and October every year with a maximum downpour between the months of July and September. The dry season lasts between the month of October and March every year. Minna average temperature is $27.3{ }^{\circ} \mathrm{C}$ while the highest temperature is $37{ }^{\circ} \mathrm{C}\left(99^{\circ} \mathrm{F}\right)$ in March and the lowest temperature is $19{ }^{\circ} \mathrm{C}\left(66^{\circ} \mathrm{F}\right)$ in December. The vegetation of the study area is dominated by grass, forming a mixture of the Southern and Northern Guinea Savanna ecological biomes. The prevailing climatic and ecologic conditions in Minna combine to support thriving agricultural practices in crop production and animal husbandry for meat production (Chukwu \& Adeoye, 2011).

Minna is drained by many drainage channels, with river Chanchaga as the main course. Its tributaries include Rivers Wana, Shaho, Godina and Dunalape (Figure 3), the study area has two reservoirs; the Bosso to the north and the Tagwai to the south of the city (Chukwu \& Adeoye, 2011).

\section{Materials and Methods}

The study covered all the six abattoirs located in Chanchaga, Tunga, UK Bello, Maitumbi, Tayi and Bosso communities within Minna metropolis (See Table 1).

The study population included: the operators of the six abattoirs and residents in the buildings within the 500 meters radius of the abattoirs stipulated by the Nigeria Environmental Impact Assessment (EIA) (EIA Act 1992; Gerber et al. 2010; Akinbode and Olujimi, 2014).

The total number of buildings that falls within the cordon area of 500-meter radius of abattoirs were counted to be 1,980. In each building, a household-head was randomly selected for the administration of the questionnaire. Agbola and Olatubara (2001) noted that to achieve good statistical representative result, 10 percent sample size is considered adequate, however, due to planning in the study area that made the buildings easily accessible, 20 percent of the total sample size of the residential buildings was randomly selected (see Table 3). 


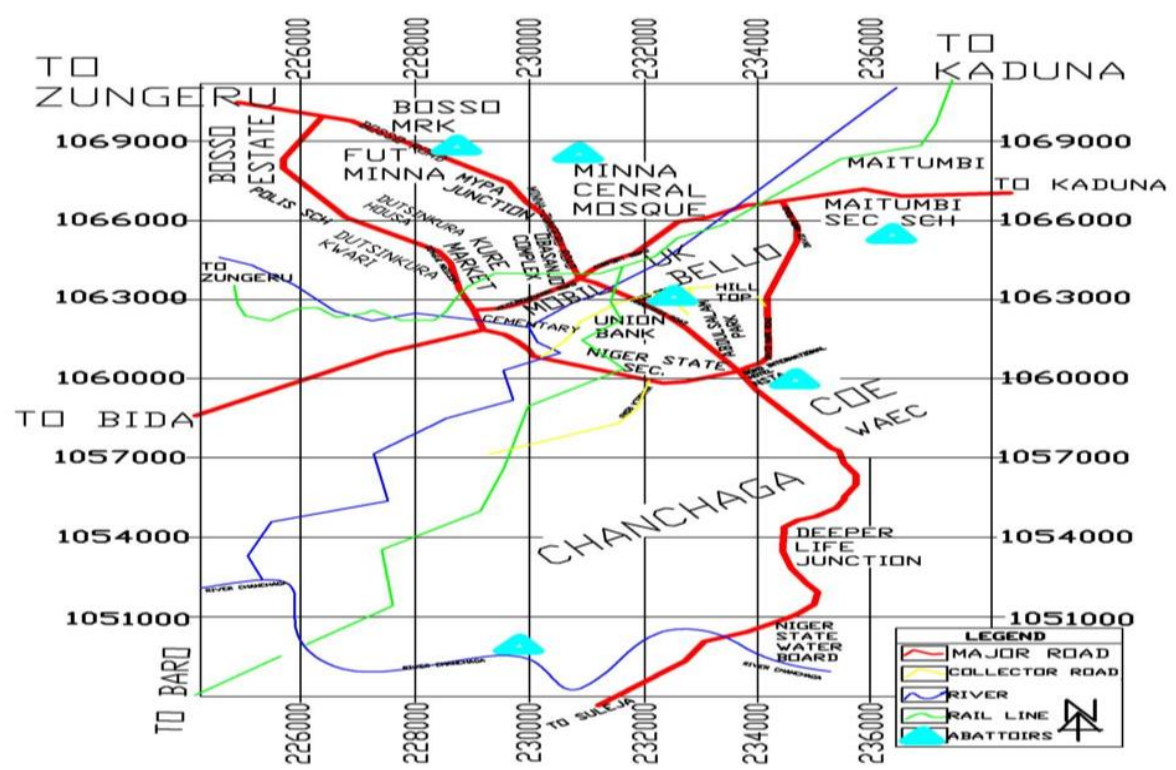

Figure 3. Map of Minna showing the locations of abattoirs.

Source: Goggle earth imagery, 2017

Table 1. Locations of Abattoirs in Minna

\begin{tabular}{llll}
\hline S/No. & Names of Abattoirs & Addresses & Locational Area \\
\hline 1 & Chanchaga Abattoir & Opposite Chanchaga water board. & Chanchaga \\
2 & Tunga Abattoir & Behind NSTA, Minna. & Tunga \\
3 & UK Bello Abattoir & Opposite UK Bello Art Theater. & UK Bello \\
4 & Maitumbi Abattoir & Behind Maitumbi Sec. Sch. Minna. & Maitumbi \\
5 & Tayi Abattoir & Tayi Village, Minna. & Tayi \\
6 & Bosso Abattoir & Behind Bosso Market,Minna. & Bosso \\
\hline
\end{tabular}

Source: Authors' Field Survey, 2017.

Primary data was collected through the administration of two (2) sets of questionnaires. The first set of questionnaires was administered on the abattoir operators while the second set was administered on the residents around the six abattoirs in Minna (See Table 2). The second set of questionnaires focused on the residents' characteristics, age, sex, occupation, effects of the abattoir on their environment and activities in the residential area around the abattoirs. Digital camera was used during reconnaissance survey to capture interesting sites in and around the abattoirs, interviews guides were used to gather information from the community chiefs. Personal observation was also used to gather information especially in areas where questions could not be asked but could be observed especially the physical state of the abattoirs, such as condition of buildings, drainages, availability of waste disposal facilities, condition of drainage etc., using checklist questionnaire to record the observations. Focus Group Discussions (FGD) were held with the abattoir operators, and the residents living within the vicinity of the abattoirs with a view to having insight into their activities and effects of the abattoirs.

Secondary data was gotten from relevant research reports and publications, magazines and journals, reports on population of the study area were sourced from National Population Commission of 2006. Map of Niger State was acquired from Niger State Ministry of Land and Survey. Information on the activities of environmental agencies of the state was sourced from Niger State Environmental Protection Agencies. Publication on Nigeria Environmental Impact Assessment (EIA) Act of 1992 and report on categorization of projects and abattoir area of influence were acquired from Federal Ministry of Environment, Abuja, Nigeria. 


\section{LAUTECH Journal of Civil and Environmental Studies \\ Volume 6, Issue 2}

Information on the operational activities of abattoir and ownership of abattoir were sought from Association of Butchers, and the map of the six abattoirs in Minna were downloaded and digitized from Google earth imageries. All the six (6) abattoirs in Minna were covered in this study. The study adopted multi-stage sampling technique for the questionnaire administration. The first stage involved delineation of the residential buildings by cordoning buildings that falls within 500-meter radius from the abattoir. A simple random sampling technique was used to obtain the 20 percent of the residential buildings that fall within 500-meter radius. The number of selected residential buildings around each of the six (6) abattoirs was 16; 44; 12; 60; 192; and 72 in Chanchaga Abattoir, Tunga Abattoir, UK Bello Abattoir, Maitumbi Abattoir, Tayi Abattoir, and Bosso abattoir, respectively.

Table 2. Sampled Sizes within the Abattoirs Cordons in Minna

\begin{tabular}{llll}
\hline S/No. & Name of Abattoir & $\begin{array}{l}\text { Number of Buildings } \\
\text { Within 500 meters radius }\end{array}$ & $\begin{array}{l}\text { 20\% of the } \\
\text { Buildings }\end{array}$ \\
\hline 1 & Chanchaga Abattoir & 80 & 16 \\
2 & Tunga Abattoir & 220 & 44 \\
3 & UK Bello Abattoir & 60 & 12 \\
4 & Maitumbi Abattoir & 300 & 60 \\
5 & Tayi Abattoir & 960 & 192 \\
6 & Bosso Abattoir & 360 & 72 \\
Total & 6 Abattoirs & 1980 & 396 \\
\hline
\end{tabular}

Source: Authors' Field Survey, 2017.

A copy of the second set of questionnaires was administered on randomly selected household-head in each of the selected building, where there were more than one household-head; coincidentally where only one household-head was living, the household-head was selected.

The procedure for data collection involved administration of questionnaires to the respondents. Five (5) research assistants were trained and engaged in the administration of the questionnaires, the procedure used in administering questionnaires varied among the two sets of questionnaires, the first set of questionnaires designed to source information from all the six abattoirs in Minna through abattoir operators was administered between $7 \mathrm{a} . \mathrm{m}$. to 9 a.m. daily during which abattoir was in operation. The second set of questionnaires designed to source information from the residents around the six abattoirs in Minna was administered between the periods of 4 p.m. to 6 p.m. every day when civil servants, traders, and farmers must have returned home after the day's job. Checklist questionnaire was used to record the author's personal observation. Focus Group Discussions (FGD) were held with the abattoir operators, and members of the Association of Butchers.

Data collected were analyzed using Statistical Package for Social Science (SPSS) version 21 to obtain frequencies, percentages, ratios where applicable. Each of the research objectives was achieved using the appropriate statistical analysis. 


\section{Results and Discussions}

The majority of the respondents were predominantly males who are in their active working age as either government employee or self-employed in which about $94.4 \%$ of them have lived in their neighbourhoods between 6 and 20 years, and such that they are more enlightened about their environment.

According to Lawan et al. (2013), inadequacy and conditions of facilities at the abattoirs are responsible for the negative effects on the environment. Findings of Omole and Ogbiye (2013) established that lack or shortage of facilities was a major contributing factor to high volumes of waste generation in abattoirs in Nigeria. The assessment of the basic amenities, facilities and their conditions in the abattoirs in Minna was therefore carried out and the results are as presented in Table 3. It revealed that Tayi abattoir has the highest facility index of 0.73 followed by Maitumbi with 0.27 facility index. UK Bello and Bosso abattoirs have indices of 0.2 and Chanchaga and Tunga abattoirs have the least facility index of 0.13 . This implied that abattoir compliance to basic requirements and standards was generally low but fair in Tayi abattoir. Shortage of facilities recorded in this study hindered standard operating procedures and good hygiene practices in the abattoirs. This posed danger to public health in Minna. The lower the facility index, the higher the unconventional practices in the abattoirs and consequently the higher the negative environmental effects.

Table 3. Availability of Basic Amenities and Facilities in the Abattoirs in Minna.

\begin{tabular}{|c|c|c|c|c|c|c|}
\hline Facilities & Chanchaga & Tunga & Uk Bello & Maitumbi & Tayi & Bosso \\
\hline Lairage & - & - & - & 1 & 1 & 1 \\
\hline Slaughter hall & 1 & 1 & - & 1 & 1 & - \\
\hline Bleeding Area & - & - & - & - & 1 & - \\
\hline Cold room & - & - & - & - & 1 & - \\
\hline First Aid & - & - & - & - & - & - \\
\hline Fire Service & - & - & - & - & - & - \\
\hline Drainage & 1 & 1 & 1 & 1 & 1 & 1 \\
\hline Water Facility & - & - & 1 & - & 1 & - \\
\hline Electricity & - & - & - & - & 1 & - \\
\hline Waste Disposal & - & - & 1 & - & - & 1 \\
\hline Admin block & - & - & - & - & 1 & - \\
\hline Disinfection & - & - & - & - & - & - \\
\hline Toilet Facility & - & - & - & 1 & 1 & - \\
\hline Waste Tank & - & - & - & - & 1 & - \\
\hline Fence & - & - & - & - & 1 & - \\
\hline $\begin{array}{l}\text { Frequency (\%) } \\
\text { Availability }\end{array}$ & $2(13 \%)$ & $2(13)$ & $3(20 \%)$ & $4(27 \%)$ & $11(73 \%)$ & $3(20 \%)$ \\
\hline Index & 0.13 & 0.13 & 0.2 & 0.27 & 0.73 & 0.2 \\
\hline
\end{tabular}

Key: Available $=1 \quad$ Not Available $=-$

Source: Authors' Fieldwork (2017) 
LAUTECH Journal of Civil and Environmental Studies

\section{Volume 6, Issue 2}

Similarly, Lawan et al. (2013) had also considered the conditions of the available facilities in Mayanka abattoir, Zango abattoir, and Kawo abattoir as a measure of abattoir's impacts on the environment. On this ground, the assessment of the conditions of basic amenities and facilities in the abattoirs in Minna was carried out and the result is as presented in Table 4. The table shows that, Tayi abattoir has the highest condition index of 0.42 ; followed by Maitumbi and UK Bello with index of 0.11, Chanchaga and Bosso abattoir have the least condition index of 0.06. This implied that abattoirs compliance to basic requirement and standard are generally low. The lower the condition of the index of facilities, the higher the unconventional practices in the abattoir and consequently the higher the negative environmental effects.

Table 4. Conditions of Basic Amenities and Facilities in the Abattoirs in Minna.

\begin{tabular}{|c|c|c|c|c|c|c|c|}
\hline Facilities & Chanchaga & Tunga & Uk Bello & Maitumbi & Tayi & Bosso & Index \\
\hline Lairage & - & - & - & 1 & 2 & - & 0.17 \\
\hline Slaughter hall & 1 & 1 & - & 1 & 2 & - & 0.28 \\
\hline Bleeding Area & - & - & - & - & 1 & - & 0.06 \\
\hline Cold room & - & - & - & - & 1 & - & 0.06 \\
\hline Drainage & 1 & 1 & 1 & 1 & 1 & 1 & 10.33 \\
\hline Water Facility & - & - & 2 & - & 1 & - & 0.17 \\
\hline Electricity & - & - & - & - & 2 & - & 0.11 \\
\hline Waste Disp. & - & - & 1 & - & - & - & 10.11 \\
\hline Admin block & - & - & - & - & 2 & - & 0.11 \\
\hline Toilet Facility & - & - & - & 1 & 1 & - & 0.11 \\
\hline Waste Tank & - & - & - & - & 1 & - & 0.06 \\
\hline $\begin{array}{l}\text { Fence } \\
\text { Condition } \\
\text { Index }\end{array}$ & 0.06 & 0.06 & 0.11 & 0.11 & 0.42 & 0.06 & 0.06 \\
\hline
\end{tabular}

Key: Satisfactory $=3$, Fairly Satisfactory $=2$, Unsatisfactory $=1$

Source: Author's Fieldwork (2017)

Food and Agricultural Organisation (2013) classified abattoirs under type of slaughtering systems while Gauteng Department of Agriculture and Rural Development (2009) classified abattoirs under the classes of animal slaughtered, according to the structural requirements as well as the maximum throughput which includes: Rural abattoirs, Low throughput abattoirs, High throughput abattoirs among others. On the basis of the aforementioned criteria for classification, the findings of this study categorized abattoirs in Minna is as follows: Fair Facility Index under which Tayi Abattoir was classified; Poor Facility Index under which Maitumbi, UK Bello, and Bosso Abattoirs were classified, and Very Poor Facility Index group included Chanchaga, and Tunga Abattoirs. These are shown in Table 5. 
Table 5. Categories of Abattoirs Based on Abattoir Facility index in Minna

\begin{tabular}{lll}
\hline Fair Facility Index & Poor Facility Index & Very Poor Facility Index \\
\hline Tayi Abattoir & Maitumbi Abattoir & Chanchaga Abattoir \\
& UK Bello Abattoir & Tunga Abattoir \\
& Bosso Abattoir & \\
\hline
\end{tabular}

Source: Authors' Fieldwork (2017).

The nature of environmental problems caused by the operation of abattoirs was classified into air pollution, water pollution, noise pollution, and poor waste disposal. Table 6 showed the nature of negative impact experienced by residents as a result of the operations of the abattoirs in their residential environment. The result shows that 69.9 percent of the residents collectively experienced various negative impacts in form of air pollution, water pollution, noise pollution, and poor waste management. And 17.5 percent of the residents experienced air pollution, 11.2 percent water pollution while those that suffered from effects of poor waste management accounted for 0.9 percent. The least negative impact from abattoir on the neighbouring residents is noise pollution which accounted for 0.5 percent based on the perception of the residents. The neighbouring residents to abattoirs suffered from various forms of environment-related challenges posed by the existence of these abattoirs within their neighbourhoods and as such put the health of the residents at risk.

Residents in the neighbourhood of abattoirs rated the level of environment-related negative impacts (air pollution, water pollution, noise pollution and poor waste management) of abattoirs using 5scale Likert Table. The result is as presented in Table 6, which shows that, residents in the neighbourhood of abattoirs experienced air pollution in form of odor impact index of 4.52, water pollution impact index of 4.02, waste disposal impact index of 3.78 and the least experienced negative environmental impact is noise pollution which accounted for 2.46. This indicates high level of environmental impacts on the abattoir neighbouring land uses.

The approved system of waste disposal in Minna abattoirs is done through the use of waste tank. However, the study identified that, five out of the six existing abattoirs have no waste tank and therefore discharged their effluent directly into open drains in the environment. Only Tayi abattoir has the waste tank facility but the tank is presently filled up, damaged, and blocked.

Table 6. Impact Level of all the Abattoirs on Residents in Minna

\begin{tabular}{lccccccc}
\hline Abattoirs & Very Low & Low & Moderate & High & Very High & W/Sum & Mean \\
\hline Air pollution & 0 & 0 & 46 & 94 & 256 & 1794 & 4.52 \\
Water pollution & 2 & 20 & 42 & 108 & 224 & 1660 & 4.02 \\
Waste & 0 & 40 & 112 & 130 & 114 & 1506 & 3.78 \\
Noise pollution & 80 & 116 & 114 & 86 & 0 & 998 & 2.46
\end{tabular}

Source: Authors' Fieldwork (2017)

Therefore, the operators bypassed the waste tank and discharged their effluents into the neighbouring environment as shown in Figures 4 and 5. 


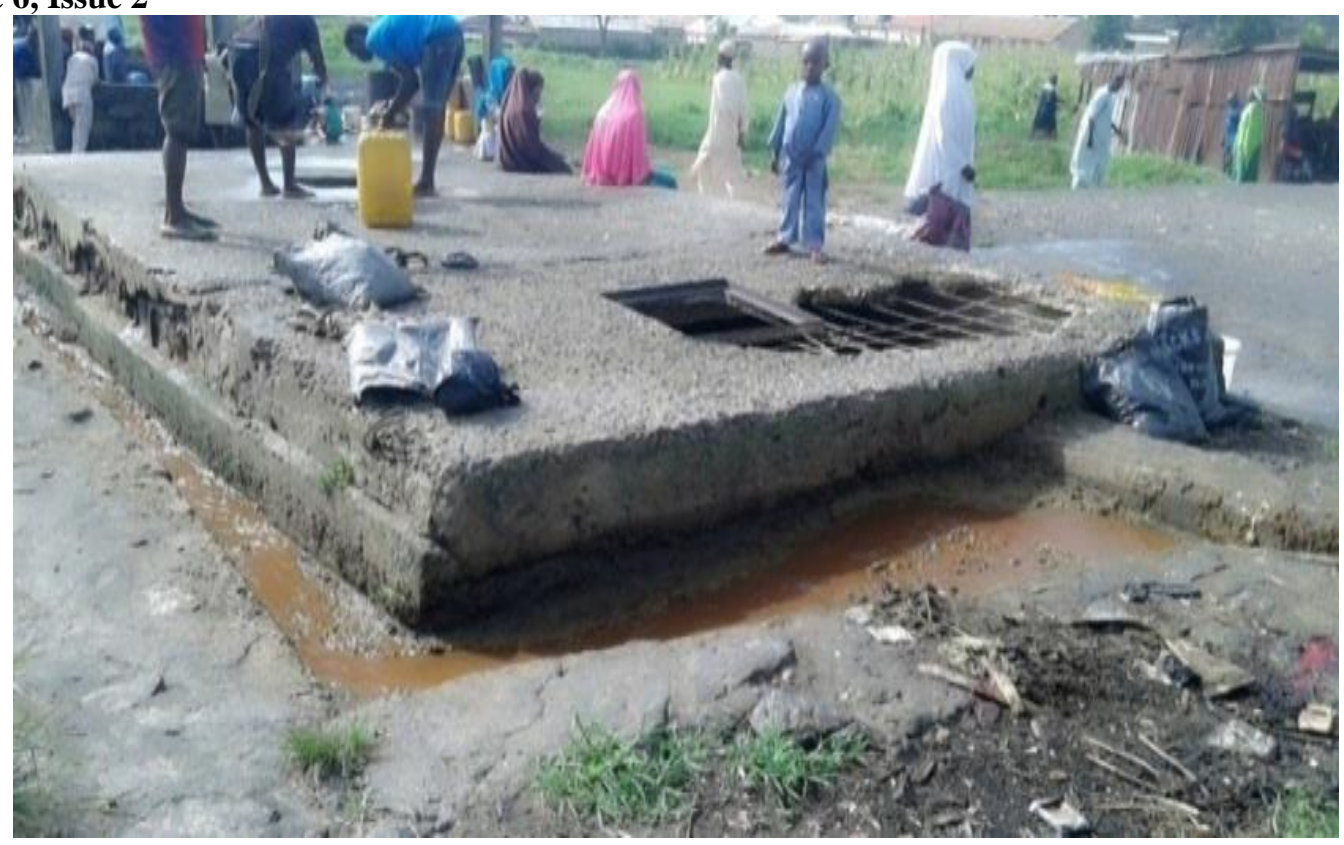

Figure 4. Waste discharged into the environment due to damaged abattoir waste tank. Source: Authors' Fieldwork (2017)

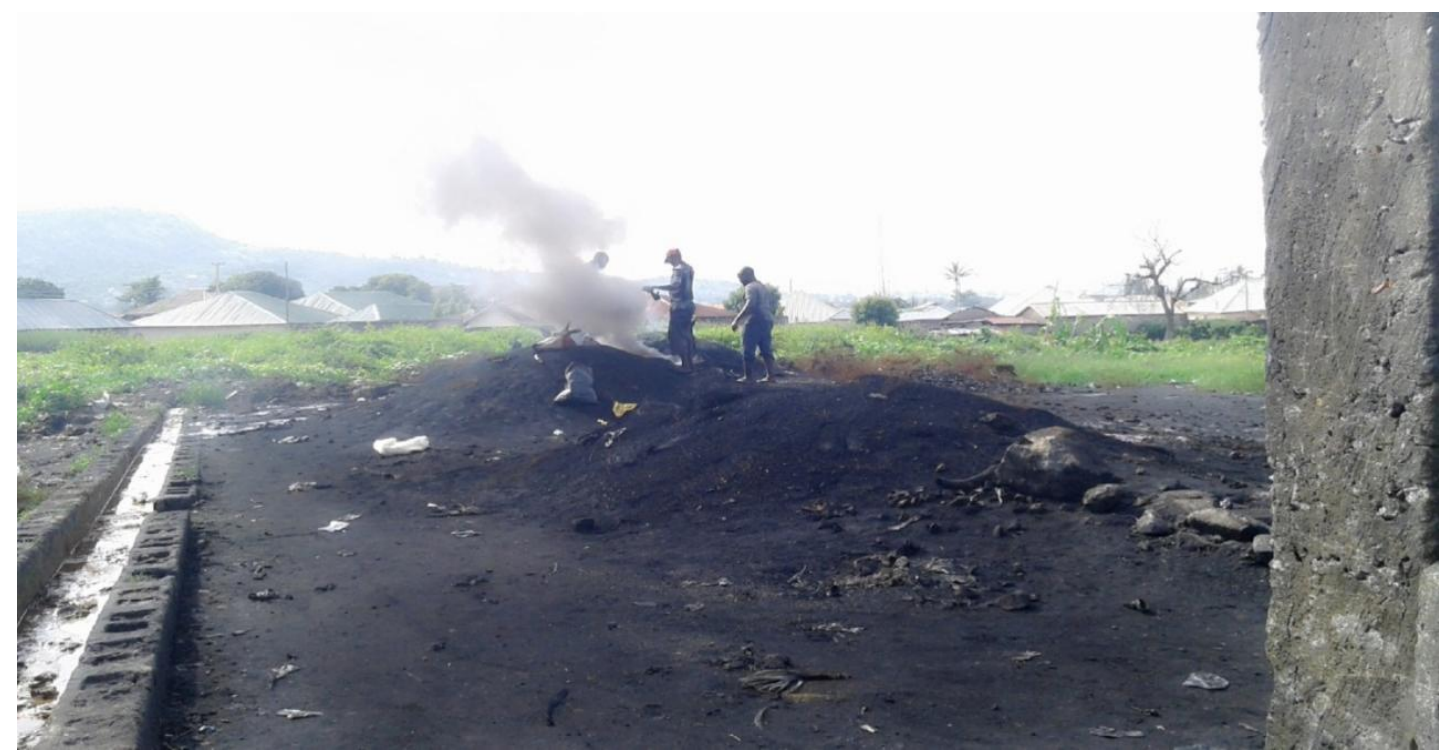

Figure 5. Air Pollution and Waste Water Flowing from Tayi Abattoir into Neighbouring Communities.

Source: Authors' Fieldwork (2017).

Out of the six abattoirs in Minna, only Tayi Abattoir had facilities for conventional water supply and water reticulation system but the facilities are presently not functional so the supply of water is done through vendor. UK Bello Abattoir was connected to pipe borne water from Niger State Water Board but short of facilities for water circulatory system. Other abattoirs like Chanchaga, Tunga, Maitumbi, and Bosso Abattoir were not connected to conventional water supply and had no facilities for water reticulation system within the abattoirs. Tayi Abattoir was the only abattoir connected to electricity supply. The unavailability of electricity in those abattoirs contributed to the un- 
conventional ways of carrying out some operations within the abattoir. Example is open roasting of animals with the use of worn-out vehicle tyres in place of electronic de-haring system. This old method emits offensive odor which pollute the environment.

\section{Conclusion and Recommendations}

This study revealed the existence of negative environmental impact in the residential areas within which abattoirs are located in Minna, Nigeria due to the operations of the abattoirs. Lack of inadequate facilities and the unconventional practices of abattoir operators were blamed for the high level of environmental damages.

It is recommended therefore that the abattoir operators should provide the lacking facilities in their abattoirs and discontinue with the unconventional practices in the operation of their abattoirs. The operational activities of abattoirs in the city should be subjected to intensive monitoring by the Inspectorate Division of the State Ministry of Health. This is to ensure that abattoirs in Niger State in general and Minna in particular operate in line with international best practices through proper management of abattoir waste.

The Niger State Urban Development Board should ensure that a buffer zone is created around the abattoirs with the use of shrubs and hedges. The buffer zone should not be less than 500 metres between abattoirs and other land uses particularly residential land use. In order to allow for the enforcement of these suggestions; the existing abattoirs in Minna should be relocated to the outskirt of the city. The relocation exercise should be implemented in piece-meal over a period of 5 years and the relocation exercise should be supervised by the Niger State Urban Development Board.

The Niger State Environmental Protection Agency (NISEPA) should promote environmental awareness among the residents and the abattoir operators in particular and residents in Minna and Niger State in general by sponsoring weekly awareness programme on Nigeria Television Authority (NTA), Niger State Television Authority (NSTV) and radio stations on areas relating to environmental-related effects of abattoirs, and other human development activities. The agency should also organize training for abattoir operators on treatment of effluents from the abattoirs and awareness programme to educate them on the negative impacts of their business operations on the environment. Government and Non-governmental Organizations should encourage those individuals that are already converting abattoir wastes into useful products by supporting them with locally fabricated machinery needed, and the training required for its operations.

The Niger State government through Niger State Environmental Protection Agency (NISEPA) should enforce the necessary provisions of the existing Environmental laws by embarking on regular inspection of abattoir facilities in Minna. The results of this study is extendable to other cities having similar climatic conditions as Minna.

\section{References}

Adeyemo, O.K. (2002). Unhygienic operation of a city abattoir in southwestern Nigeria: Environmental Implication. AJEAM/RAGEE 2002; Vol. 4, No. 1:23-28.

Adelegan, J.A (2002) 'Environmental policy and slaughterhouse waste in Nigeria, proceedings of the 28th WEDC conference Kolkata (Calcutta), India. PP 3-6

Adesemoye, A. O., Opere, B. O. and Makinde, S. C. O. (2006). Microbial content of abattoir waste water and its contaminated soil in Lagos, Nigeria. African Journal of Biotechnology, 5(20), 19631968. 
LAUTECH Journal of Civil and Environmental Studies

Volume 6, Issue 2

Agbola, T., and Olatubara, C.O. (2001). Readings in Urban and Regional Planning. Macmillian Publisher, London.

Akinbode, T., and Olujimi, J. A. B. (2014). Effects of Sawmill Wastes in Residential Areas of Ogbese and Akure Townships, Ondo State, Nigeria. International Journal of Innovation and Scientific Research, 9(2), 399-409. Retrieved from http://www.ijisr.issr-journals.org/

Akinro A.O, Ologunagba I.B, and Olotu, Y (2009) Environmental implications of unhygienic operation of a city abattoir in Akure, Western Nigeria. ARPN Journal of Engineering and Applied Sciences Vol. 4, pp. 311315.

Chukwu, O. and Adeoye, P.A (2011) Abattoir wastes generation, management and the environment: a case of Minna, North Central Nigeria. International Journal of Biosciences (IJB), Vol. 1, No. 6, p. 100-109. http://www.innspub.net

EIA Act (1992). An Act to set out the general principles, procedure and methods to enable the prior consideration of environmental impact assessment on certain public or private projects. http://extwprlegs1.fao.org/docs/pdf/nig18378.pdf

Food and Agricultural Organisation (FAO) (2013). Corporate Document on Abattoir Development Options and Designs for Hygienic Basic and Medium-Sized. http://www.fao.org/publications/sofa/2013/en/

Gauteng Department of Agriculture and Rural Development. (2009). Guideline Manual for the Management of Abattoirs and other Waste of Animal Origin.

Gerber, P., Opio, C.,\&Steinfeld, H. (2010). Poultry production and the environment. Animal Production and Health Division, Food and Agriculture Organization of the United Nations 3, 56.

Lawan M.K, Bello M, Kwaga J.K.P and Raji M.A. (2013). Evaluation of Physical Facilities and Processing Operations of major Abattoirs in North-Western States of Nigeria. Sokoto Journal of Veterinary Sciences. Vol. 11(1), 56-61.

Magaji, J.Y. and Hassan, S.M. (2015). An Assessment of Air Quality in and around Gwagwalada Abattoir, Gwagwalada, Abuja, Fct.: Journal of Environment and Earth Science,5(1), 91-92. ISSN 2225-0948

Michael K. and Konstantinos H. (2008). "Short-Term Effect of Air Pollution Levels on Pulmonary Function of Young Adults". The Internet Journal of Pulmonary Medicine 9 (2). 89-94

Miller K. A., Siscovick D. S., Sheppard L., Shepherd K., Sullivan J. H., Anderson G. L., Kaufman J. D. (2007). "Long-term exposure to air pollution and incidence of cardiovascular events in women". The New England journal of medicine 356 (5).

National Population Commission, (2006). Nigeria population growth rate. National Population Commission and National Bureau of Statistics Estimates

Omole, D. O., and Ogbiye, A. S. (2013). An Evaluation of Slaughterhouse Wastes in South-West Nigeria. American Journal of Environmental Protection. Vol. 2 (3), 88.

Osibanjo, O. and Adie, G.U. (2007) 'Impact of effluent from Bodija abattoir on the physio-chemical parameters of Oshunkaye stream in Ibadan city, Nigeria. Retrieved on 21 November, 2012. Available on line at http://www.academicjournal.org/AJB

UNDP/NISEPA. (2009). Niger state framework for integrated sustainable waste management. Niger State Strategic Waste Management Framework.

World Health Organization. (WHO). (2005) "Public Health and Air pollution" 2005", Hygienic Practice for Meat. http://www.cleanairforce.com/docs/GCAFHealthBenefitsPoster.pdf 